Liturgia Sacra 24 (2018), nr 1, s. 17-31

DOI: $10.25167 / \mathrm{LitS} / 24(2018) 1 / 17-31$

DANIEL BRZEZIŃSKI

Wydział Teologiczny, UMK

\title{
Liturgia w kluczu genetyki: analogie formalne
}

Próby opisania liturgii chrześcijańskiej za pomocą terminologii i pojęć zaczerpniętych z innych nauk, a więc poszukiwania analogii formalnych pomiędzy liturgiką i innymi dziedzinami nauki, dyscyplinami naukowymi czy obszarami wiedzy, nie są zbyt częste ${ }^{1}$. W naszym opracowaniu podejmujemy taką próbę, sięgając do genetyki, a więc nauki o dziedziczności i zmienności organizmów, które są oparte na informacji zawartej w podstawowych jednostkach dziedziczności, czyli genach.

Naszym celem jest ukazanie liturgii chrześcijańskiej w hermeneutycznym kluczu genetyki. Posługując się językiem genetyki, podejmujemy próbę opisania istoty liturgii. Tym samym pragniemy wskazać analogie formalne (z oczywistych względów inne nie mogą tutaj zachodzić) pomiędzy genetyką (jako nauką badającą mechanizmy przekazywania genów) i liturgiką, w szczególności teologią liturgii (badającą głównie sposób przekazywania i sposób obecności Misterium Chrystusa w celebrowanym misterium).

Rozpoczynamy od wyjaśnienia pojęć zawartych w tytule opracowania, by w ten sposób jednoznacznie określić zakres proponowanej refleksji.

\section{Terminologia}

Użycie terminu ,analogia” w języku potocznym najczęściej oznacza wskazanie na podobieństwo występujące między dwoma przedmiotami lub na brak tego po-

${ }^{1} \mathrm{~W}$ polskiej literaturze przedmiotu, w kluczu teorii komunikacji, czyli zbawczego dialogu pomiędzy Bogiem i Jego ludem, liturgię - blisko 30 lat temu - przedstawił B. NADOLSKI, Liturgika, t. I: Liturgika fundamentalna, Poznań 1989, s. 91-128. W podobnym układzie formalnym (liturgia jako katabasis: zstępowanie Boga ku człowiekowi; i jako anabasis: wznoszenie się człowieka ku Bogu), opracował podręcznik do liturgiki M. Kunzler, Liturgia Kościoła, Poznań 1999 (= Amateca. Podręczniki Teologii Katolickiej, t. X). 
dobieństwa. Język filozofii, zastosowany w tytule naszego opracowania w odniesieniu do terminu ,analogia”, nie odbiega od potocznych intuicji, choć w charakterystyczny dla siebie sposób je uogólnia. Intelektualne uchwycenie analogiczności bytu i wyrażenie jej w języku sprowadza się do mówienia o relacyjnej jedności tego, co złożone, i o podobieństwie tego, co zasadniczo różne 2 .

Termin ,analogia” pochodzi z języka greckiego i znaczy „odpowiedniość”, „odpowiedni stosunek”, „,upodobnienie przez proporcję” lub też „podobieństwo”, zwłaszcza oparte na odpowiedniości relacji. Samo słowo analogía składa się z przysłówka an, ana, oraz rzeczownika lógos, który z kolei pochodzi od czasownika légein. Przysłówek wskazuje na pewien stan zwielokrotnienia (,„po dwa”, „po trzy”). Natomiast czasownik można przetłumaczyć jako „składać”, „mówić”. Etymologiczny sens słowa ,analogia” wskazuje więc na istnienie jakiegoś złożonego stanu lub też na orzekanie czegoś jednego o wielu rzeczach ${ }^{3}$.

W logice orzekanie analogiczne jest szczególną odmianą orzekania wieloznacznego. „Termin jest analogicznie orzekany, gdy odnosi się do swych różnych desygnatów na zasadzie zachodzącego między nimi podobieństwa relacji”". W zabiegach naukotwórczych analogia występuje głównie bądź jako podstawa teorii modeli, bądź jako podstawa rozumowania ${ }^{5}$. W naszym opracowaniu używamy terminu ,analogia" w obydwu tych odniesieniach, zarówno w znaczeniu pewnego typu rozumowania, jak i struktury myślenia o podobnych do siebie układach.

Wśród różnych rodzajów analogii interesujące nas analogie formalne polegają na podobieństwie opisów porównywanych rzeczywistości; w naszym przypadku na zastosowaniu w liturgice terminologii i pojęć zaczerpniętych z języka genetyki.

Również termin „genetyka” (podobnie jak ,analogia”) wywodzi się z języka greckiego. Starogreckie słowo génesis oznacza „pochodzenie”. Genetyka, wyłoniona z końcem XIX w. z biologii, to nauka zajmująca się badaniem dziedziczności i zmienności żywych organizmów. Najogólniej mówiąc, analizuje mechanizmy przekazywania dziedzicznych cech, ich przejawiania się i modyfikowania ${ }^{6}$.

2 Por. J. Strzelecki, Semantyczna czy formalna teoria analogii Józefa M. Bocheńskiego?, „FiloSofija" 21 (2013), n. 2, s. 21.

3 Por. [b.a.], Analogia, w: Encyklopedia Katolicka, t. I, Lublin 1973, kol. 491; J. STRzelecki, Semantyczna czy formalna..., s. 22.

${ }^{4}$ A. StępIeń, Analogia. I: W logice, w: Encyklopedia Katolicka ..., t. I, kol. 492.

5 Por. tamże; zob. J. Herbut, Model, w: Encyklopedia Katolicka, t. XII, Lublin 2008, kol. 1481.

${ }^{6}$ Zob. A. Putrament, Genetyka, w: Encyklopedia Katolicka, t. V, Lublin 1989, kol. 955-957; T. ŚCIBOR-RYlSKA, Biologia, w: Encyklopedia Katolicka, t. II, Lublin 1976, kol. 574-575. 
Właściwości dziedziczne warunkuje zespół genów danego osobnika, czyli genotyp. Z kolei rolę nośnika informacji genetycznej organizmów żywych pełni kwas deoksyrybonukleinowy (DNA), wielocząsteczkowy organiczny związek chemiczny z grupy kwasów nukleinowych, zwany dawniej kwasem dezoksyrybonukleinowym.

Otóż, ową ,informacją genetyczną" w liturgii jest jej treść, a więc Misterium Chrystusa, czyli - używając nieco technicznego języka - zakres anamnezy liturgicznej (quod); jej aspekt materialny, liturgiczna obecność Misterium Chrystusa. „Genotypem” warunkującym „właściwości” liturgii chrześcijańskiej byłaby anamneza w jej aspekcie formalnym czy też innymi słowy: sposób (quomodo) obecności Misterium Chrystusa w sprawowanym - hic et nunc - misterium. Za „nośnik informacji”, a więc swoisty „DNA”, w którym jest zawarta „,informacja historiozbawcza”, można by uważać samą liturgię jako rzeczywistość Bosko-ludzką, wraz z jej podstawowym, anamnetycznym wymiarem; liturgię jako anamnezę Misterium Chrystusa.

Dodajmy, że problemem obecności Misterium Paschalnego Chrystusa w liturgii zajmował się genialny twórca teologii misteriów Odo Casel († 1948). Można pokusić się o stwierdzenie, również i tutaj stosując analogię formalną, że teologia misteriów Casela stała się dla współczesnej teologii liturgii tym, czym genetyka dla współczesnej medycyny?

Mysteriengegenwart, liturgiczną obecność Misterium Chrystusa, Casel rozpatrywał w obydwu - nakreślonych wyżej - aspektach. Po pierwsze, chodziło o sam fakt aktualizacji zbawczych wydarzeń (quod mysterii); po drugie - o sposób ich aktualizacji (quomodo mysterii).

7 Teoria Casela stała się centralnym problemem teologii liturgii. „Zwrot ku misteriom” był udanym poszukiwaniem odpowiedzi na fundamentalne pytania dotyczące nie tylko istoty liturgii z całym jej dynamizmem zbawczym, lecz także chrześcijaństwa w szerszym kontekście historiozbawczym. Teologia Casela to poszukiwanie istoty chrześcijaństwa; to próba odnalezienia samego centrum chrześcijańskiej egzystencji. Osoba Chrystusa jako Boga-Człowieka oraz Jego zbawcze dzieło zajmują w tych poszukiwaniach czołowe miejsce. Dlatego już w roku 1966 przyszły papież Benedykt XVI określił caseliańską Mysterientheologie jako najbardziej owocną w myśli teologicznej całego ubiegłego stulecia, a może nawet i od czasów Ojców Kościoła; por. W. ŚwIERZAwski, Dynamiczna „Pamiatka Pana”. Eucharystyczna anamneza Misterium Paschalnego i jego egzystencjalna dynamika, Kraków 1980, s. 9; W. HryNIEwICZ, Nasza Pascha z Chrystusem. Zarys chrześcijańskiej teologii paschalnej, t. II, Lublin 1987, s. 233; J. RATZINGER, Die sakramentale Begründung der christlichen Existenz, Freising 1966, s. 5; A. Bozzolo, Mistero, simbolo e rito in Odo Casel. L'effettività sacramentale della fede, Città del Vaticano 2003 (Monumenta Studia Instrumenta Liturgica, red. M. Sod, A.M. Triacca, D. Medeiros, t. XXX), s. 3-5; L.F. Conti, Mistero, simbolo e rito in Odo Casel, „Rivista Liturgica” 91 (2004), n. 4, s. 626-627; W. PAŁĘCKI, Odo Casel. Nauka o misteriach chrześcijańskich, w: J. MAJEwsKI, J. MAKowsKi (red.), Leksykon wielkich teologów XX/XXI wieku, t. III, Warszawa 2006, s. 60; A. SchiLson, Liturgia jako miejsce obecności i urzeczywistniania się tajemnic życia Jezusa, „Communio” 28 (2008), n. 1, s. 66.

8 Zob. W. Świerzawski, Odo Casel (1886-1948) - życie i dzieło, „Ruch Biblijny i Liturgiczny” 41 (1988), n. 2, s. 97-98; B. Migut, Teologia wierna misterium wedtug Odona Casela OSB (1886-1948), „Roczniki Teologiczne” 52 (2005), z. 8, s. 261-275. 
I o ile fakt obecności dzieła zbawienia w liturgii nie powoduje większych trudności w jego przyjęciu, o tyle poważniejsza trudność powstaje (stąd temu zagadnieniu poświęcimy więcej uwagi), gdy pytamy o to, jak dzieło zbawcze Chrystusa - jako wydarzenie jednostkowe, dokonane i historycznie niepowtarzalne - jest obecne w misterium liturgii .

\section{2. „Informacja genetyczna”: treść liturgii chrześcijańskiej}

Choć liturgiczna anamneza (w tej części naszego opracowania - obok swojego podstawowego znaczenia jako sposobu obecności Misterium Chrystusa i rzeczywistości stanowiącej o ontycznej tożsamości liturgii - rozumiana w sensie węższym: jako wydarzenia zbawcze wspominane w liturgii i zawarte $\mathrm{w}$ euchologii ${ }^{10}$ ) wyraziście wspomina niektóre tylko fakty z życia Chrystusa, najważniejsze elementy Jego Misterium Paschalnego, tym niemniej celebruje całą historię Chrystusa, wszystkie etapy Jego Misterium Paschalnego i całego odwiecznego planu Boga, którego punktem kulminacyjnym stał się dar Chrystusa złożony Ojcu z samego siebie za życie świata (por. Hbr 9,14). Anamneza dotyczy wspomnienia całej historii zbawienia świata $\mathrm{w}$ sensie chronologicznym i teologicznym. Liturgiczna anamneza (w znaczeniu podstawowym) wspomina, uobecnia i czyni „działającym” to wszystko, co Bóg uczynił, czego dokonuje obecnie i czego dokona w przyszłości dla zbawienia człowieka i świata ${ }^{11}$.

${ }^{9}$ W dalszej części opracowania wykorzystano: D. BRZEZIŃskI, Liturgia chrześcijańska jako celebracja wiary. Refleksja na marginesie listu apostolskiego Benedykta XVI „, Porta fidei” ogtaszajacego Rok Wiary, „Ateneum Kapłańskie” 160 (2013), z. 3, s. 438-451; TENŻE, „Chrystus wczoraj i dziś, i na wieki". Anamnetyczny wymiar roku liturgicznego, wyd. drugie poprawione i uzupetnione, Toruń 2015, s. 160-188, 208-227, 229-235, 543-553.

${ }^{10}$ Anamneza jako część euchologii chrześcijańskiej, nawiązująca często do starotestamentalnych berakot, to uwielbiające Boga wspominanie zbawczych wydarzeń. Zewnętrzną formą graficzną tego wspominania są - zapisane w księgach liturgicznych - teksty; zaś formą werbalną - odpowiadające im słowa, wypowiadane przez celebransa (celebransów) liturgii; por. M. AUGÉ, Eucologia, w: D. SARtore, A.M. Triacca (red.), Nuovo Dizionario di Liturgia, Cinisello Balsamo 1990, s. 512.

11 Por. B. Nadolski, Chwała Ojcu. Doksologie w liturgii, Poznań 1999, s. 15-16. Począwszy od starożytności chrześcijańskiej aż po czasy nam współczesne, wielu myślicieli skłaniało się bardziej ku tezie, że w liturgii obecna jest i działa moc (virtus) zasług i skutków zbawczego dzieła Chrystusa, aniżeli ku twierdzeniu, że ma tu miejsce obiektywna obecność samego Misterium Paschalnego. Tak więc w liturgii obecne byłyby jedynie skutki Tajemnicy Paschalnej w postaci łaski, a nie sama Tajemnica Paschalna. Wzmiankowany Casel przeciwstawił się - w tym aspekcie - sakramentologii scholastycznej, która podkreślała jedynie obecność skutków (effectus) zbawczego dzieła Chrystusa w postaci udzielenia łaski i aplikacji zbawienia. Tym samym „przywrócił” w dyskusji teologicznej przeświadczenie o obecności aktu zbawczego w liturgii, a nie tylko jego duchowych skutków; przeświadczenie, które znikło w ,świadomości” teologii zachodniej właściwie już u schyłku starożytności. Trzeba przy tym pamiętać, że ta koncepcja Casela była przede wszystkim rezultatem intuicji i doświadczenia, a nie spekulatywnego rozumowania. Zrodziła się pod wpływem przeżywania 
Treścią anamnezy w liturgicznych obchodach zawsze jest całe Misterium Chrystusa: od Wcielenia i Narodzenia Chrystusa (a właściwie od początku świata, kiedy to rozpoczęła się realizacja odwiecznego Bożego planu zbawczego) aż do Wniebowstąpienia, Pięćdziesiątnicy i Przyjścia Pana w dniu Paruzji12.

Wszystkie obchody liturgiczne - w ich anamnetycznym wymiarze - są od siebie zależne. Każdy z nich wyraża jakiś aspekt jedynego Misterium Chrystusa, zawsze obecnego i niepodzielonego. Obchody liturgiczne nie rozdzielają jedności Tajemnicy Paschalnej, a żadnego z celebrowanych misteriów nie można zrozumieć bez odniesienia się do Misterium Paschalnego Syna Bożego.

Liturgia celebruje obecność Chrystusa w jedynym Jego Misterium, na które składają się różne aspekty, momenty i wydarzenia zbawcze: celebruje Misterium Chrystusa w Jego misteriach. To samo dotyczy także obchodów ku czci Najświętszej Maryi Panny, aniołów oraz świętych i błogosławionych, które to obchody nie miałyby uzasadnienia, gdyby zostały oderwane od zbawczych Tajemnic z życia Pana Jezusa. Zarówno Matka Boża, jak i aniołowie, Apostołowie, męczennicy oraz wyznawcy, otaczani są w Kościele kultem ze względu na ich ścisłe powiązanie z Misterium Paschalnym Chrystusa, ze względu na ich wyjątkowe uczestnictwo w życiu i dziele Zbawiciela i w całej ekonomii zbawienia ${ }^{13}$.

liturgii i pogłębiła dzięki kontaktom z mistagogią głównie Ojców greckich; zob. W. HrYNIEwICZ, Nasza Pascha..., s. 235.

12 Teologia misteryjna Casela nie oddziela Misterium Chrystusa od całego planu zbawienia, co teolog z Maria Laach ujął następująco: „Od początku we Mszy świętej dzieje się wciąż całość. Misterium jest zawsze całe"; O. CASEL, Chrześcijańskie misterium kultu, Kraków 2000 (= Vetera et nova. Biblioteka przekładów klasyków liturgiki Instytutu Liturgicznego w Krakowie, red. S. Koperek, t. V), s. 174. Podobnie wyraził się w innym miejscu: „Każdego dnia świętujemy we Mszy świętej całe misterium Odkupienia”; tamże, s. 178. Cała Męka Chrystusa jest we Mszy świętej tak samo realiter praesens, jak substancje Ciała i Krwi; zob. W. PAŁĘCKI, Eucharystia w świetle teologii misteriów i posynodalnej Adhortacji „Sacramentum Caritatis” papieża Benedykta XVI, „Liturgia Sacra” 14 (2008), n. 2, s. 347.

13 Szeroko na ten temat zob. D. BrzezIŃSKI, ,, Chrystus wczoraj i dziś, i na wieki”..., s. 409-541. Treści liturgii dotyczyła nauka o „wiecznotrwałości” misterium odkupienia w sakramentach, głoszona przez E. Schillebeeckxa († 2009), który - w odróżnieniu od Casela (którego poglądy przedstawimy w następnym punkcie opracowania, gdyż odnoszą się przede wszystkim do aspektu formalnego anamnezy) - w obawie przed jakąś nową formą doketyzmu twierdzil, że „to, co raz miało miejsce w historii, jest nieodwołalnie faktem przeszłym i zakończonym. Wydarzenie przeszłe, historyczne nie może więc zostać na nowo zaktualizowane w sposób mistyczny czy sakramentalny. (...) Jeśli [natomiast] w sakramentach ma miejsce pewna obecność misterium, to jest to możliwe tylko dlatego, że już w zbawczym historycznym działaniu Chrystusa zawiera się element wiecznotrwały, ponadhistoryczny, który oto staje się, jako fakt ziemski, we właściwym sobie czasie, w widzialnym akcie Kościoła, elementem sakramentalnym”. Ów element jest „niezaprzeczalnie obecny w czynach, które Jezus spełniał podczas swego życia ziemskiego”. I jako że „w Jezusie-Człowieku obecny jest osobowo Syn Boży”, ,zbawcza działalność Chrystusa, która jako fakt historyczny należy nieodwołalnie do przeszłości, jest osobowym działaniem Syna Bożego, dokonanym w sposób ludzki. (...) Ponieważ ofiara krzyżowa i wszystkie tajemnice życia Chrystusowego są osobowym działaniem Boga, dlatego są wiecznie aktualne i trwałe. Sam Syn Boży jest więc obecny w tych ludzkich czynach w sposób ponadczasowy”. Schillebeeckx jednak przestrzegał, aby tej obecności „nie utożsamiać z obecnością 


\section{3. „Genotyp”: anamneza jako sposób obecności Misterium Chrystusa w liturgii}

Liturgiczna anamneza to obiektywne wspominanie i aktualizowanie hic et nunc Misterium Paschalnego Chrystusa; to obiektywna pamiątka przeszłości, ale i antycypacja przyszłości, liturgii niebiańskiej; rzecz niemożliwa - i właściwie niepojęta - dla człowieka, ale możliwa dla Boga. Wydarzenia zbawcze, które każdego dnia celebrujemy, zwłaszcza w Eucharystii, choć miały miejsce jeden jedyny raz i to w konkretnych okolicznościach czasowo-przestrzennych i historycznie nigdy się nie powtórzyły i nie powtórzą, dzięki obecności i działaniu Ducha Świętego, „żywej Pamięci Kościoła”"14, jak nazwał Go Katechizm Kościoła Katolickiego, oraz „Sprawcy cudownych dzieł Bożych, którymi są sakramenty Nowego Przymierza"15 - za każdym razem, gdy je celebrujemy (Chrystus i cały Kościół) w liturgii - stają się obecne dzisiaj na sposób sakramentalny: in mysterio, a nie tylko w skutkach czy w zbawczych owocach. Ów anamnetyczny wymiar liturgii chrześcijańskiej stanowi jej najgłębszy sens historiozbawczy. Istotą liturgii jest bowiem realna w niej obecność całego Misterium Paschalnego Chrystusa i całej historii zbawienia in mysterio.

Anamneza Misterium Chrystusa w liturgii wyklucza jakiekolwiek zawężenie jej do czysto psychologicznego czy myślnego, a więc do subiektywnego wspominania wydarzeń zbawczych: i przeszłych, i przyszłych. Obchody liturgiczne mają charakter niezależnej od człowieka, obiektywnej pamiątki, wraz z jej zbawczym kairósem, w którym Chrystus jest obecny i działa „tu” i „teraz”. To - między innymi - Casel „wyzwolił” liturgiczne hodie z możliwości błędnego pojmowania liturgii jako intelektualno-psychicznego aktu wspominania. Owa kategoria liturgicznego hodie („dzisiaj”), na nowo wydobyta przez Casela z przebogatych źródeł biblijnych i wczesnochrześcijańskich, stanowi podstawę dla zrozumienia anamnetycznego wymiaru liturgii chrześcijańskiej ${ }^{16}$.

Anamneza liturgiczna istotowo różni się nie tylko od anamnezy rozumianej jako subiektywne „odpomnienie” w platonizmie i neoplatonizmie, ale także od koncep-

samych czynów”. Mamy tutaj bowiem „obecność Osoby działającej, obecność osobową, która aktualizuje się i ujawnia w konkretnych czynach”: „Boski sposób istnienia i obecności”; por. E. ScHILLEBEECKXs, Chrystus - Sakrament spotkania z Bogiem, Kraków 1966, s. 80-83; S.C. NAPIÓRKowsKI, Z Chrystusem w znakach. Zarys sakramentologii ogólnej, Niepokalanów 1995, s. 62-65. $\mathrm{KKK})$.

${ }^{14}$ Katechizm Kościoła Katolickiego, drugie wyd. poprawione, Poznań 2002, n. 1099 (odtąd:

15 KKK 1091.

16 Por. A. LÄPple, Eucharystia. Ustanowienie, historia, uczestnictwo, Kraków 1997, s. 103. 
cji anamnezy u św. Augustyna (z jej prawdami wiecznymi, uświadamianymi sobie dzięki Bożemu oświeceniu) i od pojmowania anamnezy w - pokrewnej augustynizmowi - nowożytnej teorii natywizmu ${ }^{17}$.

Anamneza w liturgii - mimo że tutaj istnieje wiele analogii i zbieżności - jest również czymś innym niż anamneza proponowana czasem jako metoda w katechezie. Nie negując, realnej i skutecznej, zbawczej obecności Chrystusa w katechezie, trudno jednak przyznać jej charakter sakramentalny. Trudno też jest - nawet po zaaplikowaniu definicji liturgii do rzeczywistości katechezy - ujmować katechezę jako celebrację wydarzeń zbawczych in mysterio ${ }^{18}$.

Anamneza w liturgii chrześcijańskiej jest także istotowo różna od „anamnezy” w starożytnych religiach misterycznych, choć w tym wypadku można mówić o formalnej (i wyłącznie formalnej) analogii - badanej i opisanej przez Casela - pomiędzy sposobem pojmowania anamnezy w znanych nam kultach misterycznych i anammezą Misterium Chrystusa dokonującą się w liturgii chrześcijańskiej ${ }^{19}$.

Wydaje się, że wymienione sposoby rozumienia anamnezy, zwłaszcza sposób jej pojmowania w filozofii, w niemałym stopniu mogą wpływać na zniekształcone rozumienie anamnezy w liturgii. Istnieje niebezpieczeństwo redukowania anamnezy liturgicznej do wspominania i uobecnienia Misterium Paschalnego Chrystusa jedynie w jakiś psychologiczny sposób, tzn. tylko w naszej pamięci i świadomości. Tymczasem istotą liturgii i podstawą jej istnienia nie jest subiektywne wzbudzanie pamięci o wydarzeniach zbawczych, lecz realna obecność owych wydarzeń w sprawowanych - przez cały Kościół (tzn. przez Chrystusa-Głowę i członki Jego Mistycznego Ciała) - misteriach.

Dostrzeżenie istotnej i zasadniczej różnicy pomiędzy pozakultycznym (a w konsekwencji także pozaliturgicznym) rozumieniem anamnezy, z jednej strony, a jej rozumieniem w liturgii, z drugiej, pozwala na wyraziste uświadomienie sobie, że anamneza liturgiczna jest rzeczywistością obiektywną: istniejącą niezależnie od człowieka jako podmiotu poznającego czy działającego. Zresztą bez takiej właśnie anamnezy liturgia chrześcijańska - jak już to podkreśliliśmy - nie istnieje.

Aby zrozumieć sens anamnezy w liturgii, trzeba odwołać się do biblijnego znaczenia anamnezy: do starotestamentalnego zikkaron oraz nowotestamentalnego anámnesis ${ }^{20}$. Ani zikkaron, ani anámnesis w całej literaturze biblijnej jak przypomniał L. Bouyer (†2004), odwołując się do ustaleń J. Jeremiasa

\footnotetext{
17 Zob. D. BrZezińsKI, „Chrystus wczoraj i dziś, i na wieki”..., s. 29-60.

${ }^{18}$ Zob. tamże, s. 61-69.

19 Zob. tamże, s. 73-112.

${ }^{20}$ Zob. tamże, s. 119-146.
} 
$(† 1979)^{21}$ - nie powinny być rozumiane ,jako zwykła, subiektywna reminiscencja faktu z przeszłości. Zawsze chodzi o obiektywny dowód dany przez samego Boga, dowód Jego zbawczych czynów. Oznacza ich trwałość dla tych wszystkich, którzy czyny te sławią zgodnie z Jego nakazem"22.

Dzisiaj powszechnie się przyjmuje, co odnotował między innymi W. Kasper, że przy biblijnym rozumieniu pamiątki chodzi o liturgiczno-sakramentalne świętowanie, w czasie którego dawny czyn uobecnia się obiektywnie w sposób realno-symboliczny. Bez uwzględnienia biblijnej kategorii pamiątki, która uobecnia (zikkaron, anàmnesis, memoria), nie można opisać relacji liturgii chrześcijańskiej (w tym przede wszystkim Eucharystii) do Chrystusowego Krzyża i Zmartwychwstania ${ }^{23}$, przy czym termin ,anamneza” (trudny do przetłumaczenia ze względu na „cały ładunek historyczności”) „wyraża bardziej aktualizację, niż wspomnienie" ${ }^{24}$.

Obecność Misterium Chrystusa w celebracji przywoływany przez nas Casel rozumiał jako rytualne urzeczywistnienie zbawczego dzieła Chrystusa w Kościele i poprzez Kościół będący Mistycznym Ciałem Chrystusowym. Innymi słowy, jest to obecność Boskich czynów zbawczych pod osłoną znaków. ${ }^{25}$ A skoro jest to obecność czynów Boga, to uczestniczący w liturgii chrześcijanin staje się uczestnikiem Boskiej obecności i „wiecznego dzisiaj” (das ewige Heute), nie poddającemu się zasadom przygodności i czasu ${ }^{26}$.

Owa „sakramentalna obecność [Boga i Jego Misterium Paschalnego] - wyjaśnia B. Neunheuser $(† 2003)-w$ żaden sposób nie pomnaża tego, co raz na zawsze zostało dokonane w historii przez Chrystusa, ale chodzi tu raczej o uczestnictwo hic et nunc - w jednorazowym, historycznym czynie zbawczym Chrystusa. Znak, który tę rzeczywistość przekazuje, jest więc symbolem rzeczywistym, wspomnieniem, które się w tym symbolu wyraża; jest wspomnieniem rzeczywistym, a nie tylko subiektywnym”27. Łaska sakramentalna zaś jest „czymś więcej, niż tylko

${ }^{21}$ Wnikliwe badania biblijne dotyczące Ostatniej Wieczerzy zostały zamieszczone w dziele: J. Jeremias, Die Abendmahlsworte Jesu, Göttingen 1967. s. 134 .

${ }^{22}$ L. BOuYer, Od liturgii żydowskiej do liturgii chrześcijańskiej, „Kolekcja Communio” 1 (1986),

${ }^{23}$ Por. W. Kasper, Jedność Eucharystii i wielość jej aspektów, „Kolekcja Communio” 1 (1986), s. 24.

${ }^{24}$ P. De Clerck, Zrozumieć liturgię, Kielce 1997, s. 144.

25 Por. O. CASEL, Mysteriengegenwart, ,Jahrbuch für Liturgiewissenschaft” 8 (1929), s. 145.

${ }^{26}$ Por. TEnżE, Chrześcijańskie misterium, s. 177; W. Hryniewicz, Nasza Pascha, s. 239-240.

27 B. Neunheuser, Problem obecności misterium w liturgii w dziełach O. Casela, ,Ruch Biblijny i Liturgiczny" 41 (1988), n. 2, s. 132. 
owocem wydarzenia [zbawczego]. Jest po prostu samym wydarzeniem w postaci sakramentalnej”28.

Analiza istoty misterium chrześcijańskiego i jej określenie doprowadziły Casela do sprecyzowania sposobu aktualizacji Misterium Paschalnego Chrystusa w liturgii chrześcijańskiej. Ów sposób, nazywany przez Casela Mysteriengegenwart, to obiektywne uobecnienie dzieła zbawczego w misterium kultu; obiektywne uobecnienie nie tylko działającej łaski dzieła zbawczego, lecz uobecnienie („teraźniejszość”) samego dzieła Odkupienia, będącego źródłem tej łaski. Na określenie tego stanu Casel używa terminu Gegenwärtigsetzung, które odpowiada łacińskiemu terminowi re-praesentatio. Rzadziej używa słowa Vergegenwärtigung, co można by przetłumaczyć jako „uprzytomnienie”, gdyż ten ostatni termin mógłby niesłusznie sugerować uobecnienie jedynie subiektywne (przede wszystkim myślne), a więc jakąś formę uobecnienia dokonującego się wyłącznie w podmiocie działającym ${ }^{29}$.

\section{4. „DNA”: liturgia jako anamneza Misterium Chrystusa}

Pojęcie „,anamnezy” stało się we współczesnej teologii liturgii dominantą określającą liturgię. Bez zrozumienia istoty anamnezy nie sposób zrozumieć istotę liturgii chrześcijańskiej. Bez anamnezy liturgia nie jest po prostu liturgią. Anamneza, w tym anamnetyczna obecność Misterium Chrystusa, jest podstawowym kryterium klasyfikacyjnym odróżniającym ,liturgię” od „nie-liturgii”30.

Liturgia chrześcijańska, będąc przede wszystkim zbawczym działaniem Boga, a nie tylko zwykłym czynem laudatywnym człowieka, nie posiada (gdyż jako rzeczywistość Bosko-ludzka nie może posiadać) wyczerpującej czy też w pełni adekwatnej definicji. Liturgię można próbować opisać w różnych aspektach, ale nie da się jej zdefiniować. W liturgii chrześcijańskiej dokonuje się spotkanie Misterium Boga i misterium wiary z życiem człowieka. Bóg wchodzi w ludzką egzystencję „tu i teraz”, a ludzie uczestniczą w życiu Boga. Formułowanie więc jakichkolwiek definicji liturgii zawsze stanowi jedynie, mniej lub bardziej udaną, próbę zrozumienia jej natury $\mathrm{i}$ istoty przez analogię ${ }^{31}$.

28 W. Hryniewicz, Nasza Pascha, s. 232.

29 Por. W.J. PAŁĘCKI, Odo Casel, s. 53-54.

${ }^{30}$ Zob. D. BRZEZIŃSKI, , Liturgia” $i$, nie-liturgia”: w poszukiwaniu kryteriów klasyfikacji, „Liturgia Sacra" 31 (2008), n. 1, s. 69-82.

${ }^{31}$ Zob. TENŻE, W poszukiwaniu teologicznego sensu liturgii. Refleksje na 2000-lecie chrześcijaństwa, „Studia Płockie” 28 (2000), s. 37. 
Odwieczny Bóg z chwilą, kiedy „Słowo stało się ciałem i zamieszkało między nami” (por. J 1,14), bezpośrednio wkroczył w historię stworzonego przez siebie świata i związał się z czasem. Wraz z wcieleniem Syna Bożego dokonała się consecratio mundi: świat stał się sakramentem odkupienia, historia wszechświata i człowieka stała się historią świętą, a czas otrzymał wymiar zbawczy. Nastała „pełnia czasu" i rozpoczął się nowy, zbawczy kairós. Liturgia jest niczym innym jak owym kairós czy też ciągiem kairo ${ }^{32}$. W tym sensie jest „nośnikiem” zbawienia, zarówno w sensie obiektywnym, jak i w wymiarze subiektywnym, dotyczącym każdej osoby ludzkiej powołanej przez Boga do zbawienia.

Według Konstytucji o Liturgii Sacrosanctum Concilium II Soboru Watykańskiego i Katechizmu Kościoła Katolickiego (gdzie w zasadzie powtarza się kluczowe stwierdzenia z Konstytucji, gdy chodzi o próbę teologicznego opisu liturgii chrześcijańskiej), liturgia jest dziełem Chrystusa-Głowy i Jego Kościoła: „wykonywaniem kapłańskiej funkcji Jezusa Chrystusa; w niej [w liturgii] przez znaki dostrzegalne wyraża się, i w sposób właściwy dla poszczególnych znaków dokonuje, uświęcenie człowieka, a Mistyczne Ciało Jezusa Chrystusa, to jest Głowa ze swymi członkami, sprawuje pełny kult publiczny"33.

Opisując istotę liturgii chrześcijańskiej, zarówno Konstytucja jak i Katechizm przypominają, że zmartwychwstały Chrystus, udzielając Apostołom Ducha Świętego, powierzył im oraz ich następcom władzę uświęcania i zbawiania. Ta ,sukcesja apostolska" przekazywana jest od dwudziestu wieków przez sakrament święceń. Dzięki sakramentalnemu kapłaństwu - co mocno podkreślał między innymi Pius XII $\left(†\right.$ 1958) w Encyklice o Liturgii Mediator Dei $i^{34}$ - możliwe jest nieprzerwane sprawowanie liturgii, w której Chrystus oraz działający in Persona Christi biskupi i prezbiterzy wciąż uobecniają to samo dzieło, jakie dokonało się podczas Ostatniej Wieczerzy, na drzewie Krzyża i w Poranek Wielkanocny. W ten sposób ziemska liturgia staje się kolejnym etapem historii zbawienia. Po okresie Starego Testamentu (kiedy ludzkość oczekiwała Zbawiciela) i po nastaniu ,pełni czasów” w Nowym Testamencie (gdy Chrystus pojednał nas z Bogiem Ojcem), dzisiaj nasze zbawienie i uświęcenie dokonuje się w liturgii Kościoła, która z kolei jest zapowiedzią i przedsmakiem liturgii niebieskiej. Czas Kościoła jest więc kontynuacją cza-

${ }^{32}$ Zob. D. BRZEZIŃSKI, „Chrystus wczoraj i dziś, i na wieki”..., s. 273-309; TENŻE, Liturgiczny kairos czasem eschatycznej nadziei i jej wypetnienia, w: K. FILIPOwICZ (red.), ,, Chlubimy się nadzieja chwaty Bożej" (Rz 5,2). Ksiega dedykowana ks. prof. dr. hab. Janowi Decykowi, Warszawa 2016, s. $117-129$.

${ }^{33}$ Konstytucja o Liturgii Świętej Sacrosanctum Concilium, w: Sobór WaTYKaŃSKi II, Konstytucje. Deklaracje. Dekrety, tekst polski, nowe tłumaczenie, Poznań 2002, n. 7 (odtąd: KL); por. KKK 1070.

${ }^{34}$ Zob. PIUs XII, Encyklika o Liturgii Mediator Dei, Kielce 1948, s. 28-29. 
su Chrystusa. Dzieje się tak nie tylko poprzez prosty i oczywisty fakt następstwa czasowego. „Linię kontynuacji”, jak ją nazwał S. Marsili († 1983), łączącą czas Kościoła z czasem Chrystusa, konstytuuje święta liturgia ${ }^{35}$.

„Jak Ojciec posłał Chrystusa - czytamy w Konstytucji o Liturgii - tak i On [Chrystus] posłał Apostołów, których napełnił Duchem Świętym, nie tylko po to, aby głosząc Ewangelię wszystkiemu stworzeniu, zwiastowali, że Syn Boży swoją śmiercią i zmartwychwstaniem wyrwał nas z mocy Szatana i uwolnił od śmierci oraz przeniósł do Królestwa Ojca, lecz także po to, aby ogłaszane dzieło zbawienia sprawowali przez Ofiarę i sakramenty" ${ }^{\prime 36}$.

Aby odkupienie przyniesione przez Chrystusa realizowało się w każdym człowieku poprzez jego osobowe uczestnictwo w Tajemnicy Paschalnej, Misterium Paschalne musi być skutecznie obecne w Kościele. Liturgia Kościoła, ześrodkowana wokół znaków czerpiących swą nadprzyrodzoną skuteczność z historycznych czynów Chrystusa, jest właśnie tą zbawczą, skuteczną aktualizacją Misterium Paschalnego w czasie ${ }^{37}$. B. Nadolski określa to jako związek działania mimetycznego z działaniem uobecniającym zbawcze czyny Jezusa. Liturgia łączy nierozdzielnie obydwa te elementy. „Najpierw chodzi o przyjęcie tego, co się dokonało, a więc liturgia jest wspomnieniem, memoria, memoriale, anamnezą czynu Chrystusa (...). Ten czyn Jezus Chrystus obecny w zgromadzeniu liturgicznym, w mocy Ducha Świętego, uobecnia; Jezus Chrystus jest obecny i jego dzieło - kapłaństwo Chrystusa - Jesu Christi sacerdotalis muneris exercitatio" 38 .

Tak więc, liturgia to przede wszystkim dzieło samego Chrystusa i anàmnesis oraz mimesis Jego Misterium Paschalnego. Chrystus, Bóg-Człowiek, Najwyższy i Wieczny Kapłan - podobnie jak przed dwoma tysiącami lat podczas swojego ziemskiego życia, tak i dzisiaj, za każdym razem, gdy sprawowana jest liturgia pod osłoną znaków składa sam siebie w Ofierze Bogu Ojcu, który jest Celem i Źródłem liturgii ${ }^{39}$.

Liturgia to historiozbawczy skarb Kościoła. Dzięki niej - ujmując rzecz nieco kolokwialnie - nie musimy ,żałować” czy też „się martwić”, iż nie żyjemy w cza-

35 Por. KL 5-8; KKK 1077-1090; S. MARsil, La liturgia - momento storico della salvezza, w: TENŻE (red.), Anàmnesis. Introduzione storico-teologica alla liturgia, t. I: La liturgia - momento nella storia della salvezza, Casale Monferrato 1988 (ristampa), s. 91-92; D. BrzezIŃski, Liturgia jako ostatni ziemski etap historii zbawienia, „Studia Płockie” 27 (1999), s. 37-41.

${ }^{36}$ KL 6; por. D. BrzezIŃski, W poszukiwaniu teologicznego sensu liturgii..., s. 46-47.

37 Por. W. Hryniewicz, Liturgia a Misterium Paschalne Chrystusa, w: F. Blachnicki, W. Schenk, R. Zielasko (red.), Wprowadzenie do liturgii, Poznań, 1967, s. 89.

${ }^{38}$ B. Nadolski, Wprowadzenie do liturgii, Kraków 2004 (Myśl Teologiczna, red. A. Baron, H. Pietras, t. XLII), s. 23.

39 Por. KKK 1077-1083. 
sach Chrystusa, gdyż - poprzez jej anamnetyczny wymiar - wszystkie wydarzenia zbawcze sprzed dwóch tysięcy lat są obecne „tu” i „teraz” za każdym razem, gdy sprawujemy świętą liturgię Kościoła. Obecność ta - czyniąc realną hic et nunc przeszłość - antycypuje jednocześnie eschatyczną przyszłość: Niebieskie Jeruza$\mathrm{lem}^{40}$. I tak będzie aż do skończenia świata.

$* * *$

Zaproponowane poszukiwanie analogii formalnych pomiędzy liturgiką i genetyką oraz szukanie nowego języka i nowych form opisu liturgii jest próbą ukazania i popularyzacji właściwego rozumienia liturgii chrześcijańskiej. W owej propozycji - jak nietrudno zauważyć - nie chodziło, absolutnie, o podejmowanie zagadnień semantycznych i nadawanie nowego znaczenia pojęciom oraz terminom przyjętym w teologii liturgii i w teologii liturgicznej, zarówno w przeszłości, jak i obecnie; wręcz przeciwnie. Zastosowanie hermeneutycznego klucza genetyki miało na celu wydobycie najgłębszej istoty liturgii chrześcijańskiej, jej teologicznego sensu i historiozbawczego znaczenia w życiu ludzkim, gdyż właśnie tyle (tylko tyle i aż tyle) może oznaczać (i de facto oznacza) mówienie - per analogiam - o „genetyce liturgii”.

\section{Streszczenie}

W opracowaniu ukazano liturgię chrześcijańską w hermeneutycznym kluczu genetyki. Posługując się językiem genetyki, podjęto próbę opisania istoty liturgii. Tym samym wskazano analogie formalne (z oczywistych względów inne nie mogą tutaj zachodzić) pomiędzy genetyką (jako nauką badającą mechanizmy przekazywania genów) i liturgiką, w szczególności teologią liturgii (badającą głównie sposób przekazywania i sposób obecności Misterium Chrystusa w celebrowanym misterium).

Słowa kluczowe: liturgia chrześcijańska, genetyka, anamneza, analogia formalna

${ }^{40}$ Zob. D. BrzezIŃSKI, Liturgia skarbem Kościoła. Historiozbawczy wymiar liturgii chrześcijańskiej, w: M. ChoJnacki, J. Morawa, A.A. NAPIÓRKowsKi (red.), O bogactwach Kościoła, Kraków 2014 (= Cracoviensis Cogitatio Ecclesialis, t. VI), s. 13-25. 


\section{Liturgy in the key of genetics: formal analogies}

\section{Abstract}

In the article Christian liturgy is presented in the hermeneutic key of genetics. It is an attempt to describe the essence of liturgy using the language of genetics. Thus the text identifies formal analogies (due to obvious reasons other forms of analogy cannot exist in this case) between genetics as the study of mechanisms which determine heredity of genes and liturgics, the theology of liturgy in particular, which studies the way of passing on and the presence of Christ's Mystery in the celebration of mystery.

Keywords: Christian liturgy, genetics, anamnesis, formal analogy.

\section{Bibliografia}

Augé M., Eucologia, w: D. Sartore, A.M. Triacca, C. Balsamo (red.), Nuovo Dizionario di Liturgia, red 1990, s. 509-519.

[b.a.], Analogia, w: Encyklopedia Katolicka, t. I, Lublin 1973, kol. 491-492.

Bouyer L., Od liturgii żydowskiej do liturgii chrześcijańskiej, „Kolekcja Communio" 1 (1986), s. 127-139.

Bozzolo A., Mistero, simbolo e rito in Odo Casel. L'effettività sacramentale della fede, Città del Vaticano 2003 (= Monumenta Studia Instrumenta Liturgica, red. M. Sodi, A.M. Triacca, D. Medeiros, t. XXX).

BrzezIŃski D., Chrystus wczoraj $i$ dziś, i na wieki. Anamnetyczny wymiar roku liturgicznego, Toruń 2015 r.

BRZEZIŃSKI D., Liturgia chrześcijańska jako celebracja wiary. Refleksja na marginesie listu apostolskiego Benedykta XVI „Porta fidei” ogłaszającego Rok Wiary, „Ateneum Kapłańskie” 160 (2013), z. 3, s. 438-451.

BRZEZIŃSKI D., Liturgia i „nie-liturgia”: w poszukiwaniu kryteriów klasyfikacji, „Liturgia Sacra” 31 (2008), n. 1, s. 69-82.

BRZEZIŃSKi D., Liturgia jako ostatni ziemski etap historii zbawienia, „Studia Płockie" 27 (1999), s. 37-41.

BrzezIŃsKi D., Liturgiczny ,, kairos” czasem eschatycznej nadziei i jej wypetnienia, w: K. FILIPOwICz (red.), Chlubimy się nadzieją chwały Bożej (Rz 5,2). Ksiega dedykowana ks. prof. dr. hab. Janowi Decykowi, Warszawa 2016, s. 117-129. 
BRZEZIŃSKI D., Liturgia skarbem Kościoła. Historiozbawczy wymiar liturgii chrześcijańskiej, w: M. ChoJnacki, J. Morawa, A.A. Napiórkowski (red.), O bogactwach Kościoła, Kraków 2014 (= Cracoviensis Cogitatio Ecclesialis, t. VI), s. 13-25.

BRZEZIŃSKI D., W poszukiwaniu teologicznego sensu liturgii. Refleksje na 2000-lecie chrześcijaństwa, „Studia Płockie” 28 (2000), s. 37-48.

Casel O., Chrześcijańskie misterium kultu, Kraków 2000 (= Vetera et nova. Biblioteka przekładów klasyków liturgiki Instytutu Liturgicznego w Krakowie, red. S. Koperek, t. V).

CAsel O., Mysteriengegenwart, „Jahrbuch für Liturgiewissenschaft” 8 (1929), s. $145-224$.

ConTI L.F., Mistero, simbolo e rito in Odo Casel, „Rivista Liturgica” 91 (2004), n. 4 , s. 626-636.

De Clerck P., Zrozumieć liturgię, Kielce 1997.

Herbut J., Model, w: Encyklopedia Katolicka, t. XII, Lublin 2008, kol. 1481.

Hryniewicz W., Liturgia a Misterium Paschalne Chrystusa, w: F. Blachnicki, W. Schenk, R. Zielasko (red.), Wprowadzenie do liturgii, Poznań 1967, s. $75-98$.

Hryniewicz W., Nasza Pascha z Chrystusem. Zarys chrześcijańskiej teologii paschalnej, t. II, Lublin 1987.

Jeremias J., Die Abendmahlsworte Jesu, Göttingen 1967.

KASPER W., Jedność Eucharystii i wielość jej aspektów, „Kolekcja Communio” 1 (1986), s. 19-40.

Katechizm Kościoła Katolickiego, drugie wyd. poprawione, Poznań 2002.

Konstytucja o Liturgii Świętej „Sacrosanctum Concilium”, w: SobóR WatykaŃSKI II, Konstytucje. Deklaracje. Dekrety, tekst polski, nowe thumaczenie, Poznań 2002, s. 48-78.

Kunzler M., Liturgia Kościoła, Poznań 1999 (= Amateca. Podręczniki Teologii Katolickiej, t. X).

Läpple A., Eucharystia. Ustanowienie, historia, uczestnictwo, Kraków 1997.

MARSili S., La liturgia - momento storico della salvezza, w: teNże (red.), Anàmnesis. Introduzione storico-teologica alla liturgia, t. I: La liturgia - momento nella storia della salvezza, Casale Monferrato 1988, s. 31-156.

Migut B., Teologia wierna misterium wedtug Odona Casela OSB (1886-1948), „Roczniki Teologiczne” 52 (2005), z. 8, s. 261-275.

Nadolski B., Chwata Ojcu. Doksologie w liturgii, Poznań 1999.

Nadolski B. Liturgika, t. I: Liturgika fundamentalna, Poznań 1989. 
Nadolski B, Wprowadzenie do liturgii, Kraków 2004 (= Myśl Teologiczna, red. A. Baron, H. Pietras, t. XLII).

NAPIÓRKowsKi S.C., Z Chrystusem w znakach. Zarys sakramentologii ogólnej, Niepokalanów 1995.

Neunheuser B., Problem obecności misterium $w$ liturgii $w$ dziełach O. Casela „Ruch Biblijny i Liturgiczny” 41 (1988), n. 2, s. 129-135.

PAŁĘCKI W., Eucharystia w świetle teologii misteriów i posynodalnej Adhortacji „Sacramentum Caritatis” papieża Benedykta XVI, „Liturgia Sacra” 14 (2008), n. 2, s. 343-361.

PAŁĘCKI W., Odo Casel. Nauka o misteriach chrześcijańskich, w: J. MaJeWsKI, J. MAKowsKi (red.), Leksykon wielkich teologów XX/XXI wieku, t. III, Warszawa 2006, s. 49-61.

PIUs XII, Encyklika o Liturgii Mediator Dei, Kielce 1948.

Putrament A., Genetyka, w: Encyklopedia Katolicka, t. V, Lublin 1989, kol. 955957.

Ratzinger J., Die sakramentale Begründung der christlichen Existenz, Freising 1966.

Schilson A., Liturgia jako miejsce obecności i urzeczywistniania się tajemnic życia Jezusa, „Communio” 28 (2008), n. 1, s. 63-75.

SchillebeeckXs E., Chrystus - Sakrament spotkania z Bogiem, Kraków 1966.

StępIEŃ A., Analogia. I: W logice, w: Encyklopedia Katolicka, t. I, Lublin 1973, kol. 492.

StRzelecki J., Semantyczna czy formalna teoria analogii Józefa M. Bocheńskiego?, „Filo-Sofija” 21 (2013), n. 2, s. 21-38.

Ścibor-RYlska T., Biologia, w: Encyklopedia Katolicka, t. II, Lublin 1976, kol. 573-577.

Ś WierzaWski W., Dynamiczna „Pamiątka Pana”. Eucharystyczna anamneza Misterium Paschalnego i jego egzystencjalna dynamika, Kraków 1980.

Świerzawski W., Odo Casel (1886-1948) - zyycie i dzieło, „Ruch Biblijny i Liturgiczny" 41 (1988), n. 2, s. 89-105.

DANIEL BRZEZIŃSKI - prezbiter diecezji płockiej; dr hab. nauk teologicznych; dr liturgiki; profesor i senator Uniwersytetu Mikołaja Kopernika w Toruniu; profesor w Papieskim Instytucie Liturgicznym św. Anzelma w Rzymie; kustosz Kapituły Katedralnej Płockiej; wiceprezes Towarzystwa Naukowego Płockiego; e-mail: danbr@op.pl. 